\title{
AMELIORATIVE ROLE OF GARLIC (ALLIUM SATIVUM) ON CHROMIUM (VI) - INDUCED MEMBRANE DAMAGE IN MALE ALBINO RATS
}

\author{
SOUMITA DEY, SANKAR KUMAR DEY* \\ Department of Physiology, Santal Bidroha Sardha Satabarshiki Mahavidyalaya (Affiliated to Vidyasagar University), Paschim Medinipur, \\ West Bengal, India. Email: sdeybiomed@gmail.com \\ Received: 02 June 2021, Revised and Accepted: 10 July 2021
}

\section{ABSTRACT}

Objective: Membrane damage is one of the most important consequences of chromium (Cr) induced cytotoxicity. Garlic possesses antioxidant property to scavenge the toxic radicals and cytoprotective activity. The aim of the present investigation is to evaluate the ameliorative role of aqueous extract of garlic (AEG) on Cr-induced membrane damage of both liver and kidneys in male albino rats.

Methods: Male albino rats of Wistar strain (80-100 g) were used for the present study. Rats were divided into three groups of almost equal average body weight. The animals of two groups were injected $\mathrm{K}_{2} \mathrm{Cr}_{2} \mathrm{O}_{7}$ at a dose of $0.8 \mathrm{mg}$ per $100 \mathrm{~g}$ body weight per day for 28 days. The animals of one of the Cr-treated groups served as the supplemented group supplied AEG (250 mg per kg body weight daily at an interval of $6 \mathrm{~h}$ after injection of Cr for a period of 28 days). The animals of the remaining group received only the vehicle ( $0.9 \% \mathrm{NaCl})$, served as control. The body weights of the animals were taken in each day of treatment schedule.

Results: The results indicated that significant increases in membrane cholesterol, as well as significant decreases in membrane phospholipid in $\mathrm{Cr}$, exposed animals suggest structural alterations in both liver and kidneys plasma membrane. Alkaline phosphatase (ALP), total ATPase, and $\mathrm{Na}^{+}-\mathrm{K}^{+}$- ATPase activities of the plasma membrane were significantly decreased in both liver and kidneys after Cr treatment. On the other hand, AEG supplementation plays a vital role to restore such alterations induced by $\mathrm{Cr}$ in the plasma membrane of both liver and kidney.

Conclusion: These findings indicate that $\mathrm{Cr}$ treatment at the present dose and duration induces structural and functional alterations in the plasma membrane in both liver and kidney. However, AEG supplementation restored those alterations induced by Cr in the plasma membrane of both liver and kidneys but was not able to eliminate the deposited $\mathrm{Cr}$ from the liver and kidney tissues.

Keywords: Chromium, Liver, Kidney, Plasma membrane, Aqueous extract of garlic.

(C) 2021 The Authors. Published by Innovare Academic Sciences Pvt Ltd. This is an open access article under the CC BY license (http://creativecommons.org/ licenses/by/4.0/) DOI: http://dx.doi.org/10.22159/ajpcr.2021v14i9.42274. Journal homepage: https://innovareacademics.in/journals/index.php/ajpcr

\section{INTRODUCTION}

Chromium (Cr) is a naturally occurring heavy metal found commonly in the environment in two valence states: Trivalent $\mathrm{Cr}$ (III) and hexavalent $\mathrm{Cr}$ (VI). Cr (VI) is widely used in steel, alloy cast iron, chrome plating, leather tanning, paints, metal finishes, and wood treatment. Cr plays a dual role in nature with $\mathrm{Cr}$ (III) essential for glucose and lipid metabolism [1]. However, excessive intakes of $\mathrm{Cr}$ (VI) compounds are potent toxicants and carcinogens [2]. Hepatic and renal toxicity is the most common toxicity found in $\mathrm{Cr}(\mathrm{VI})$-exposed workers or animals [3]. This functional differentiation of $\mathrm{Cr}$ (III) and $\mathrm{Cr}$ (VI) is largely decided by the ionic permeability of the plasma membrane [4]. Thus, membrane damage is one of the crucial factors observed with Cr (VI) toxicity [5].

Garlic (Allium sativum) is an herb used for the treatment of variety of diseases [6]. The anti-carcinogenic and anti-inflammatory properties of garlic extract and its derivatives also have recently been reported by several investigators [7]. Garlic compounds are having tremendous antioxidant property which exerts action by scavenging ROS, enhancing cellular antioxidant enzymes, and increasing glutathione in the cells [8]. Our previous studies showed that antioxidants such as Vitamins and GSH were able to ameliorate Cr (VI)-induced membrane damage in the liver and kidneys [5,9,10].

However, to the best of our knowledge no information is available regarding the role of garlic in $\mathrm{Cr}(\mathrm{VI})$-mediated cell membrane damage. Therefore, the aim of this present investigation was an attempt to reduce the effects of $\mathrm{Cr}$-induced cytotoxicity using garlic in vivo in terms of certain structural and functional components like cholesterol and phospholipids levels as well as alkaline phosphatase (ALP), total ATPase, and $\mathrm{Na}^{+}-\mathrm{K}^{+}$- ATPase activities of the liver and kidneys plasma membrane.

\section{METHODS}

\section{Collection of plant materials}

Plant parts, i.e., the fresh bulb of garlic were collected from the market. Each specimen was labeled with date of collection. Plant parts were cleaned and peeled off. Then, plant parts were dried in incubator $<40^{\circ} \mathrm{C}$.

\section{Preparation of aqueous extract of garlic (AEG)}

Clean dry plant sample was collected in a cotton bag. The material was grinded to fine powder with the help of mixer grinder. Then this powdered material was used for the preparation of aqueous extract. $2 \mathrm{~g}$ of powdered material was mixed with $20 \mathrm{ml}$ of sterile distilled water and kept on a rotary shaker for $12 \mathrm{~h}$ at $38^{\circ} \mathrm{C}$. Thereafter, it was filtered with the help of Whatman No. 1 filter paper. The filtrate was then centrifuged at $2000 \mathrm{rpm}$ for $10 \mathrm{~min}$. Then the supernatant was collected and stored at $4^{\circ} \mathrm{C}$ for further use.

\section{Maintenance and treatment of animals}

Male albino rats of the Wister strain (80-100 g) were fed with a labprepared diet, as described elsewhere [11], with water ad libitum. They were maintained in accordance with the guidelines of the rule of the Institutional Animal Ethics Committee. Laboratory acclimatized rats were divided into three groups of almost equal average body weight. The animals of two groups were injected intraperitoneally (i.p.) with $\mathrm{Cr}$ as $\mathrm{K}_{2} \mathrm{Cr}_{2} \mathrm{O}_{7}$ at a dose of $0.8 \mathrm{mg}$ per 100 g body weight per day $\left(20 \% \mathrm{LD}_{50}\right)$ for 
28 days, as described earlier [11]. The animals of one of the Cr-treated groups served as the supplemented group injected AEG orally at a dose of $250 \mathrm{mg}$ per $\mathrm{kg}$ body weight daily at an interval of $6 \mathrm{~h}$ after injection of $\mathrm{Cr}$ for a period of 28 days. The animals of the remaining group received only the vehicle $(0.9 \% \mathrm{NaCl})$, which served as control.

\section{Tissue collection}

After the experimental period, overnight fasting rats were sacrificed by cervical dislocation. The liver and kidneys were immediately dissected out of the body and weighed. The tissues were then quickly stored at $-20^{\circ} \mathrm{C}$. The concentration of $\mathrm{Cr}$ was measured in the liver and kidneys by atomic absorption spectrometry.

\section{Isolation of crude membrane fraction}

Membrane fractions of the liver and kidneys were isolated according to the method described by Chaudhuri et al. [12]. Tissues were homogenized with a glass homogenizer in $0.25 \mathrm{~mol} \mathrm{~L}^{-1}$ cold sucrose solutions. The homogenates were then centrifuged at $15,000 \times \mathrm{g}$ for $15 \mathrm{~min}$ at $4^{\circ} \mathrm{C}$. The supernatants were collected and centrifuged again at $22,650 \times \mathrm{g}$ for $20 \mathrm{~min}$ at $4^{\circ} \mathrm{C}$. The supernatants, thus obtained, were discarded and the pellets were suspended in $1 \mathrm{~mL}$ chilled Tris buffer $(\mathrm{pH} 7)$ after three washings with the same buffer.

\section{Assay of membrane protein}

Membrane protein was estimated using Folin-Ciocalteau reagent according to the method of Lowry et al. [13] using bovine serum albumin as the standard.

\section{Estimation of membrane cholesterol and phospholipid}

Cholesterol and phospholipid levels of the isolated membrane fractions were estimated by the methods of Zlatkis et al. [14] and Christopher and Ralph [15], respectively.

\section{Measurement of ALP activity}

ALP activity of the isolated membrane fractions were assayed using p-nitrophenyl phosphate as substrate according to the method of Linhardt and Walter [16].

\section{Determination of total ATPase and $\mathrm{Na}^{+}-\mathrm{K}^{+}$- ATPase activities}

Total ATPase and $\mathrm{Na}^{+}-\mathrm{K}^{+}$- ATPase activities were measured by the method of Sen et al. [17].

\section{Statistical analysis}

Results were expressed in terms of mean and standard error of different groups. The differences between the mean values were evaluated by ANOVA followed by multiple Student's t-tests. The values for $\mathrm{p}<0.05$ were considered significant.

\section{RESULTS}

Changes in the rat's body weight during the period of treatment are depicted in Fig. 1. It was found that the body weights of $\mathrm{Cr}$ treated rats are significantly decreased when compared with control. Further, bodyweight of $\mathrm{Cr}$ treated rats remained increased when supplemented with AEG.

Upon exposure to $\mathrm{Cr}$, the liver and kidneys showed significant increases in metal content. Supplementation of Cr-treated rats with AEG did not prevent the elevation of $\mathrm{Cr}$ content in the liver and kidneys (Table 1). Whereas the weight of the liver significantly increased but the kidney weights remained unaltered. Supplementation with AEG prevented changes in the liver weight (Table 1).

Alterations in membrane cholesterol and phospholipids levels of liver and kidney were presented in Figs. 2 and 3. Significant increased in membrane cholesterol and decreased in membrane phospholipids contents in response to $\mathrm{Cr}$-treated group were noted. AEG administered to Cr-treated rats plays a vital role to counteract the levels of cholesterol and phospholipids in the liver and kidney plasma membrane.

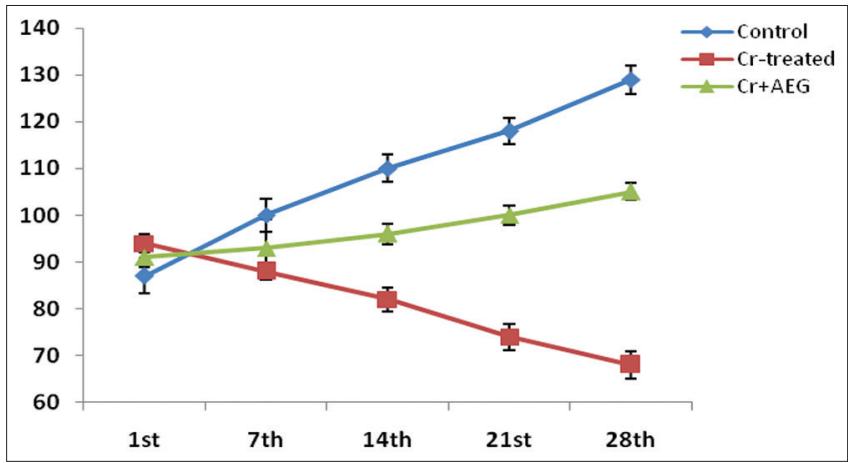

Fig. 1: Changes in body weight after co-administration of aqueous extract of garlic to chromium-treated rats

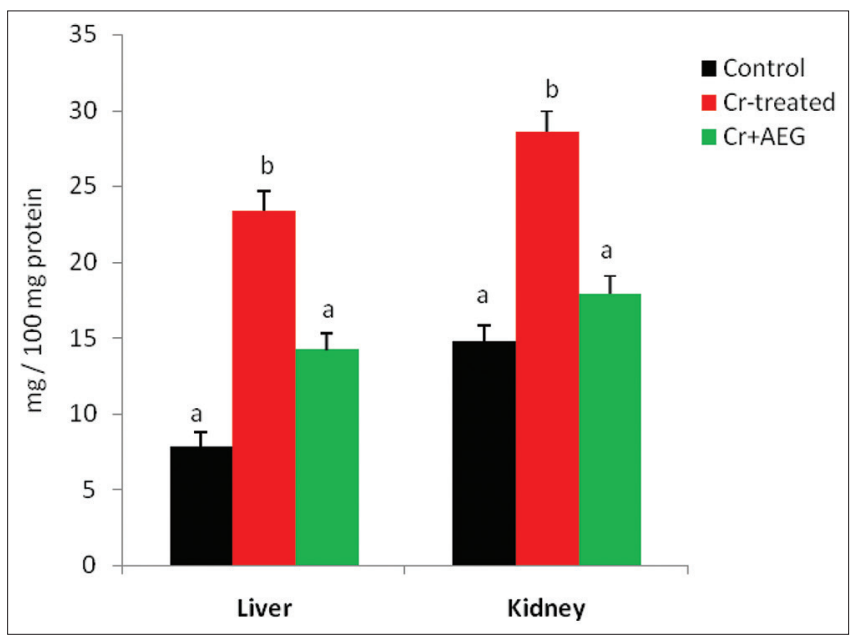

Fig. 2: Changes in membrane cholesterol level after coadministration of aqueous extract of garlic in chromium-treated rats. Data represent mean $\pm S E, p<0.05$, and ANOVA followed by multiple comparisons Student's t-test. Same superscript in each vertical column did not differ from each other significantly

Table 1: Tissue weight and $\mathrm{Cr}$ content of organs after co-administration of AEG in $\mathrm{Cr}$-treated rats

\begin{tabular}{llcc}
\hline Tissues & $\begin{array}{l}\text { Groups of } \\
\text { animals }\end{array}$ & $\begin{array}{c}\text { Organ weight } \\
\text { (g per 100 g bw) }\end{array}$ & $\begin{array}{c}\text { Cr content } \\
\text { ( } \boldsymbol{\mu g} \text { ger g tissue) }\end{array}$ \\
\hline Liver & Control & $2.99 \pm 0.10^{\mathrm{a}}$ & $0.31 \pm 0.03^{\mathrm{a}}$ \\
& Cr+treated & $4.23 \pm 0.22^{\mathrm{b}}$ & $2.89 \pm 0.12^{\mathrm{b}}$ \\
& Cr+AEG & $3.16 \pm 0.26^{\mathrm{a}}$ & $2.83 \pm 0.18^{\mathrm{b}}$ \\
Kidney & Control & $0.81 \pm 0.06^{\mathrm{a}}$ & $1.09 \pm 0.08^{\mathrm{a}}$ \\
& Cr+treated & $0.79 \pm 0.05^{\mathrm{a}}$ & $6.32 \pm 0.34^{\mathrm{b}}$ \\
& Cr+AEG & $0.78 \pm 0.03^{\mathrm{a}}$ & $6.25 \pm 0.39^{\mathrm{b}}$ \\
\hline
\end{tabular}

Data represent mean $\pm S E, p<0.05$, and ANOVA followed by multiple comparisons, Student's t-test. Same superscript in each vertical column did not differ from each other significantly, AEG: Aqueous extract of garlic, Cr: Chromium

Data represented Figs. 4- 6 that ALP, total ATPase, and $\mathrm{Na}^{+}-\mathrm{K}^{+}$-ATPase activities in the plasma membrane of the liver and kidney were significantly decreased in $\mathrm{Cr}$-treated group. With the simultaneous administration of AEG, ALP, total ATPase, and $\mathrm{Na}^{+}-\mathrm{K}^{+}$-ATPase activities returned to nearly normal level but not reversed completely.

\section{DISCUSSION}

Based on a comparison of body weight gain on $\mathrm{Cr}$ exposed rat with that of control (Fig. 1), it appears that weight gain was decreased in Cr-treated rats. The impact on body weight due to the direct effect of 


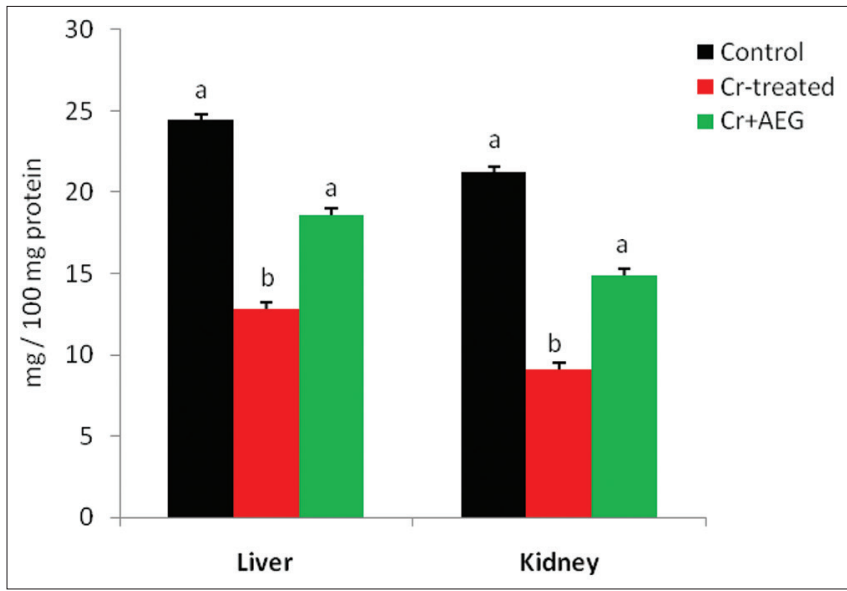

Fig. 3: Changes in membrane phospholipid level after co-administration of aqueous extract of garlic in chromium-treated rats. Data represents mean $\pm S E, p<0.05$ and ANOVA followed by multiple comparisons Student's t-test. Same superscript in each vertical column did not differ from each other significantly

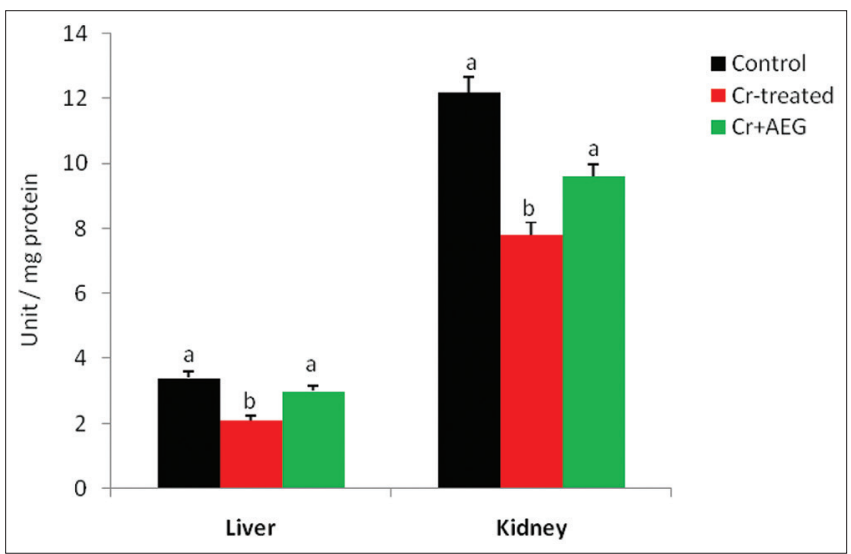

Fig. 4: Changes in membrane ALP activity after co-administration of aqueous extract of garlic in chromium-treated rats. Data represents mean $\pm S E, p<0.05$ and ANOVA followed by multiple comparisons Student's t-test. Same superscript in each vertical column did not differ from each other significantly

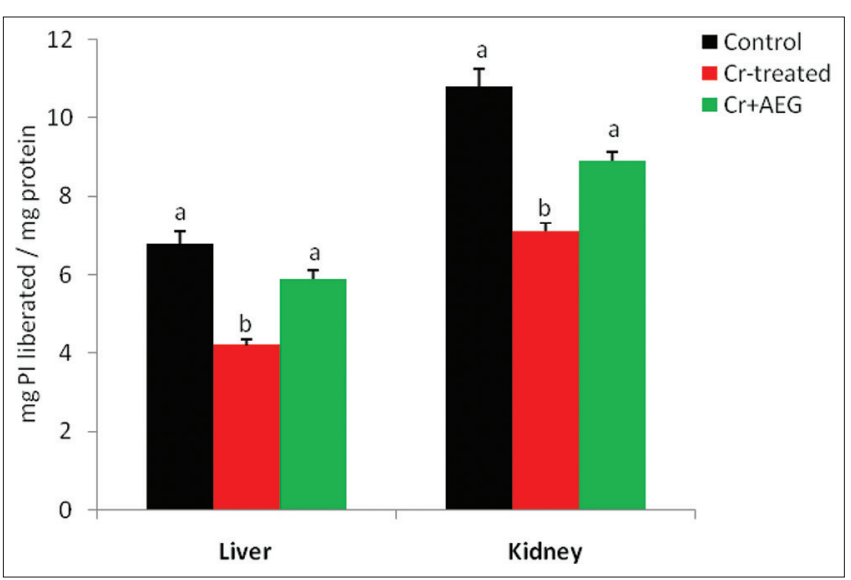

Fig. 5: Changes in membrane ATPase activity after co-administration of aqueous extract of garlic in chromium-treated rats. Data represents mean $\pm S E, p<0.05$ and ANOVA followed by multiple comparisons Student's t-test. Same superscript in each vertical column did not differ from each other significantly

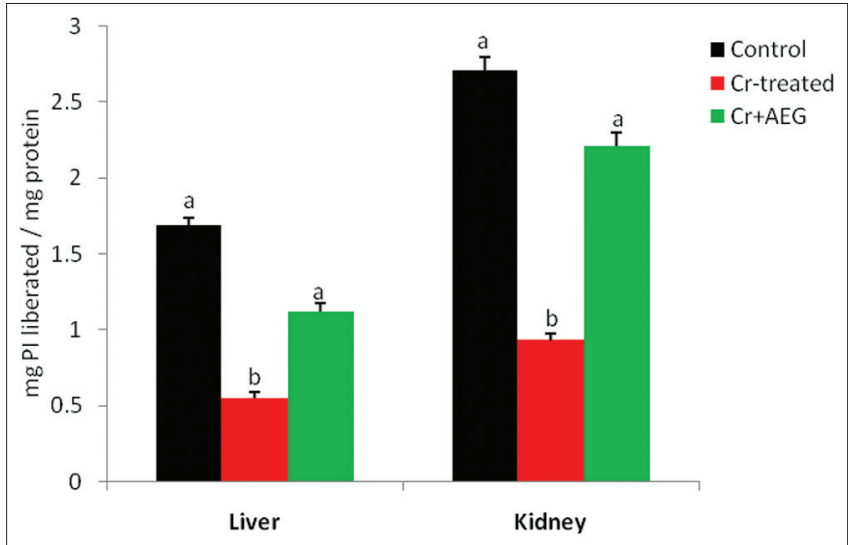

Fig. 6: Changes in membrane Na+-K+-ATPase activity after co-administration of aqueous extract of garlic in chromium-treated rats. Data represent mean $\pm S E, p<0.05$, and ANOVA followed by multiple comparisons Student's t-test. Same superscript in each vertical column did not differ from each other significantly

$\mathrm{Cr}$ and not due to reduce food intake as control rats were pair-fed with the Cr-treated rat. Supplementation of Cr-treated animals with AEG partially reversed the body weight fall to control levels.

The lowered body weight was not reflected in organ weight, as recorded just after sacrifice (Table 1). Only the liver showed a significant increase in weight. Similar results were reported in our laboratory [11] suggesting that $\mathrm{Cr}$ treatment at the given dose and duration increased the liver weight but the kidneys remain unaltered. Thus, $\mathrm{Cr}$ appears to have a differential impact on organ size but after supplementation with AEG restored the changes in organ weights following metal exposure.

The $\mathrm{Cr}$ content of the liver and kidney tissues was increased significantly following $\mathrm{Cr}$ treatment (Table 1). The increased levels of $\mathrm{Cr}$ in all tested organs studied following $\mathrm{Cr}$ treatment were found to be unaffected by supplementing $\mathrm{Cr}$-treated rats with AEG. This shows that supplementation with AEG was not able to reduce the load of accumulated metal in the tissues. It was reported that protection with deferoxamine against $\mathrm{Cr}$ was not attributed to either a reduced $\mathrm{Cr}$ uptake by the cells or alterations in $\mathrm{Cr}$ distribution within cells [18]. It was also reported that pre-treatment with vitamin $\mathrm{E}$ and melatonin did not affect $\mathrm{Cr}$ uptake or distribution in cells after metal treatment $[19,20]$. Sugiyama [21] also demonstrated that the uptake of $\mathrm{Na}_{2} \mathrm{CrO}_{4}$ was not affected by pre-treatment with vitamin E. From the present study, it may be suggested that AEG exerted no effect on $\mathrm{Cr}$ uptake and distribution in different organs after metal treatment. Whether such supplementation has any impact on the distribution of different forms of $\mathrm{Cr}$ within the cells remains to be ascertained by further studies.

Various studies indicated that both hexavalent and trivalent $\mathrm{Cr}$ are biologically active oxidation states [18]. It was suggested that an oxidative impact of $\mathrm{Cr}(\mathrm{VI})$ on membrane phospholipids indicates a probable structural alteration of the membrane [22]. On the other hand, activation of the membrane-bound enzyme indicates a functional alteration of the membrane [23].

In the present investigation, the $\mathrm{Cr}$-induced membrane damaged was clearly indicated by significantly increases of the membrane cholesterol content in the both liver and kidneys (Fig. 2). This rise may be due to imbalance in cholesterol incorporation into the membrane. Thus, $\mathrm{Cr}$ impaired the function of lecithin cholesterol acetyltransferase. On the other hand, decreased membrane phospholipids levels (Fig. 3) indicated that the damage of membrane structure of the cell. The probable impact of $\mathrm{Cr}$ on the lipid catabolizing enzymes cannot be ruled out as evidenced by increased excretion of urinary lipid metabolites [24]. This 
enhanced catabolism of lipid may result in the accumulation of acetyl Co-A, which in term may lead to increased synthesis of cholesterol in the tissues particularly in nonsteroid producing tissues. Thus, $\mathrm{Cr}$ by altering the relative proportion of cholesterol and phospholipids may produce cellular damaged to the membrane structure. The impact of $\mathrm{Cr}$ on membrane cholesterol and phospholipids contents was found to disappear when $\mathrm{Cr}$ was accompanied by AEG. It was reported that serum cholesterol level is increased in response to $\mathrm{Cr}$, but the simultaneous treatment of garlic extract relatively improved serum cholesterol level [25]. Evidence indicates that this structural change of both liver and kidneys plasma membrane is attenuated by the AEG supplementation.

This report of impact of $\mathrm{Cr}$ on ALP activity of tissue membrane is contradictory $[1,18,26]$. After $\mathrm{Cr}$ treatment, the activity of ALP in the plasma membrane of both the liver and kidneys was found to be decreased (Fig. 4) as observed in our earlier studies $[5,9,10]$. This inhibition of ALP activity reflects selective damage of the plasma membrane [26], which is also supported by alterations in cholesterol and phospholipid contents (Figs. 2 and 3). In the present investigation, results indicate that the supplementation with AEG completely attenuated $\mathrm{Cr}$-induced inhibition of membrane ALP activity of both the liver and kidneys.

Total ATPase activity of membrane was reduced significantly in the $\mathrm{Cr}$ treated group in kidney but AEG supplementation cannot completely attenuated $\mathrm{Cr}$-induced inhibition of kidney membrane total ATPase activity (Fig. 5). The inhibition of the energy production by cytotoxic concentration of $\mathrm{Cr}$ [27] may play some role in Cr-induced changes of the ATPase activity. $\mathrm{Na}^{+}-\mathrm{K}^{+}-$ATPase activity was found to be reduced significantly in $\mathrm{Cr}$ treated organ (Fig. 6). The observed results are supported by findings on $\mathrm{Cr}$-induced reduction of membrane transport $[28,29]$. When the Cr-treated group was supplemented with AEG, the $\mathrm{Na}^{+}-\mathrm{K}^{+}$ATPase activity was found to restore in the kidney plasma membrane.

\section{CONCLUSION}

These findings indicate that $\mathrm{Cr}$ treatment at the present dose and duration induces structural and functional alteration in the kidney plasma membrane. The structural and functional changes may be attenuated by AEG supplementation. The protective action of AEG might be due to the presence of one or more principal component in garlic. However, more detailed studies are needed to elucidated the exact mechanism underlying $\mathrm{Cr}$ induced membrane damaged.

\section{ACKNOWLEDGMENT}

The authors are thankful to Vidyasagar University, Midnapore for providing the facilities to execute these studies.

\section{AUTHORS' CONTRIBUTIONS}

Both authors contributed equally.

\section{CONFLICTS OF INTEREST}

There is no conflict of interest.

\section{AUTHORS' FUNDING}

Self.

\section{REFERENCES}

1. Chorvatovicová D, Kováciková Z, Sandula J, Navarová J. Protective effect of sulfoethylglucan against hexavalent chromium. Mutat Res 1993;302:207-11.

2. de Flora S, Bagnasco M, Serra D, Zanacchi P. Genotoxicity of chromium compounds.A review. Mutat Res 1990;238:99-2.
3. Hojo Y, Satomi Y. In vitro nephrotoxicity induced in mice by chromium (VI): Involvement of glutathione and chromium (V). Biol Trace Elem Res 1991;31:21-1.

4. de Flora S, Watterhahn KE. Mechanism of chromium metabolism and genotoxicity. Life Chem Rep 1989;7:169-75.

5. Dey SK, Roy S. Role of GSH in the amelioration of chromium-induced membrane damage. Toxicol Environ Chem 2010;92:261-9.

6. Prasad K, Laxdal VA, Yu M, Raney BL. Evaluation of hydroxyl radicalscavenging property of garlic. Mol Cell Biochem 1996;154:55-3.

7. Kalayarasan S, Sriram N, Sureshkumar A, Sudhandiran G. Chromium (VI) -induced oxidative stress and apoptosis is reduced by garlic and its derivative S-allylcysteine through the activation of Nrf2 in the hepatocytes of Wistar rats. J Appl Toxicol 2008;28:908-19.

8. Borek C. Antioxidant health effects of aged garlic extract. J Nutr 2001;131:1010-5.

9. Dey SK, Nayak P, Roy S. Chromium-induced membrane damage: Protective role of ascorbic acid. J Environ Sci 2001;13:272-5.

10. Dey SK, Nayak P, Roy S. Alpha-tocopherol supplementation on chromium toxicity: A study on rat liver and kidney cell membrane. J Environ Sci (China) 2003a;15:356-9.

11. Dey SK, Roy S, Chatterjee AK. Effect of chromium on certain aspects of metabolic toxicities. Toxicol Mech Methods 2003b;13:89-5.

12. Chowdhuri AG, Sen P, Ganguli U. Alteration of the microenvironment in plasma membranes of rat enterocytes after Escherichia coli heat stable enterotoxin treatment: Effect on protein kinase C activity. Biochem Mol Biol Int 1995;35:567-74.

13. Lowry OH, Rosebrough NJ, Farr AL, Randall RJ. Protein measurement with the folin phenol reagent. J Biol Chem 1951;193:265-75.

14. Zlatkis A, Zak B, Boyle AJ.A new method for the determination of serum cholesterol. J Lab Clin Med 1953;41:486-92.

15. Christopher SF, Ralph TD. Standard Methods of Clinical Chemistry. Vol. 7. New York: Acedemic Press; 1972.

16. Linhardt K, Walter K. Phosphatase (phosphomonoestekases). In: Bergmeyer H, editor. Methods of Enzymatic Analysis. New York: Academic Press; 1963. p. 779-87.

17. Sen PC, Kapakos JG, Steinberg M. Phosphorelation and dephosphorylation of $\mathrm{Mg}^{+2}$ independent $\mathrm{Ca}^{+2}$-ATPase from goat spermatozoa. Arch Biochem Biophys 1981;211:652-61.

18. Susa N, Ueno S, Furukawa Y, Sugiyama M. Protective effect of deferoxamine on chromium (VI)-induced DNA single-strand breaks, cytotoxicity, and lipid peroxidation in primary cultures of rat hepatocytes. Arch Toxicol 1997a;71:345-50.

19. Susa N, Ueno S, Furukawa Y, Sugiyama M. Protective effect of Vitamin E on chromium (VI)-induced cytotoxicity and lipid peroxidation in primary cultures of hepatocytes. Arch Toxicol 1996;71:20-4.

20. Susa N, Ueno S, Furukawa Y, Ueda J, Sugiyama M. Potent protective effect of melatonin on chromium (VI)-induced DNA single-strand breaks, cytotoxicity, and lipid peroxidation in primary cultures of rat hepatocytes. Toxicol Appl Pharmacol 1997b;144:377-84.

21. Sugiyama M. Effects of Vitamin E and Vitamin B2 on chromateinduced DNA lesions. Biol Trace Elem Res 1989;21:399-5.

22. Ginter E, Chrovatovicova D, Kosinova A. Vitamin C lowers the mutagenic and toxic effects of hexavalent chromium in guinea pigs. Int J Vitam Nutr Res 1989;59:161-6.

23. Bagchi $\mathrm{D}$, Bagchi $\mathrm{M}$, Tang L, Stohs SJ. Comparitive in vitro and in vivo proteinkinase $\mathrm{C}$ activation by selected pesticides and transition metal salts. Toxicol Lett 1997;91:31-7.

24. Bagchi D, Hassoun EA, Bagchi M, Stohs SJ. Chromium-induced excretion of urinary lipid metabolites, DNA damage, nitric oxide production and generation of reactive oxygen species in SpragueDawley rats. Comp Biochem Physiol C Pharmacol Toxicol Endocrinol 1995;110:177-82.

25. Chi MS, Koh ET, Steriat TJ. Effect of garlic on lipid metabolism in rats fed cholesterol or lard. J Nutr 1982;112:241-8.

26. Kumar A, Rana SS. Enzymological effects of hexavalent chromium in the rat kidney. Int J Tissue React 1984;4:135-9.

27. Stohs SJ, Bagchi D. Oxidative mechanisms in the toxicity of metal ions. Free Radic Biol Med 1995;18:321-36.

28. Standeven AM, Wetterhahn KE. Possible role of glutathione in chromium(VI) metabolism and toxicity in rats. Pharmacol Toxicol 1991a;68:469-76.

29. Standeven AM, Wetterhahn KE. Ascorbate is the principal reductant of chromium (VI) in rat liver and kidney ultrafiltrates. Carcinogenesis $1991 b ; 12: 1733-7$ 